ROTONDARO, Tatiana Gomes. Human action in a Genomic Era: debates on human nature. História, Ciências, Saúde - Manguinhos, Rio de Janeiro, v.16, n.1, jan.-mar. 2009, p.157-170.

\title{
Abstract
}

The supposed properties of 'genes' have led natural scientists to claim authority to explain the reasons of human action, behavior, and even human nature, which has traditionally been the object of study of the humanities. The aim of this paper is to discuss the possibilities of sociological theory dealing with the biological reductionism that establishes the strict articulation between 'human nature' and 'human action', presented in several speeches and papers by scientists and journalists and supported by features of 'genes'. I intend to argue that sociological theories may broaden their scope of analysis by encompassing biological dimensions, which does not necessarily mean adopting a biological reductionist approach.

Keywords: social theory; human action; human nature; genomics; genetics.

Resumo

As supostas propriedades dos 'genes' levam os cientistas naturais a reivindicar autoridade para explicar as razões de atos, comportamentos e até a natureza humana, tradicional objeto de estudo das ciências humanas. O objetivo deste artigo é discutir as possibilidades de a teoria sociológica lidar com o reducionismo biológico, que estabelece uma articulação exata entre 'natureza humana' e 'ação humana'. Tal reducionismo está presente em discursos e artigos de cientistas e jornalistas, e é embasado por características dos 'genes'. Argumento que as teorias sociológicas podem ampliar suas possibilidades de análise se incorporarem dimensões biológicas, o que não implica necessariamente adotar uma abordagem reducionista.

Professora do Departamento de Sociologia Pontifícia Universidade Católica de Campinas Rua Paula Freitas, 19/508 22040-010 Rio de Janeiro - RJ - Brasil tatianarotondaro@puc-campinas.edu.br

Palavras-chave: teoria social; ação humana; natureza humana; genoma; genética. 
$\mathrm{T}$ he problem of 'human action' and the relationship between 'structure' and 'agency' have rightly come to be seen as the basic issue in modern social theory (Archer, 1988; Giddens, 1984; Domingues, 1995). The promises of individual improvements through biotechnology and genomic and genetic developments, especially as broadcast by the media, have engendered a series of questions and speculations about the impact of these technologies on human agency, as well as about the possibility of new constraints over individuals. The urgent need to understand what these developments have represented to humankind has frequently forwarded the debate of the classic problem of human nature. Inquiring about the implications of this scenario for contemporary sociological theory, this paper will follow some steps to present and to debate some issues that these scientific and technological developments have presented to social analysis.

In order to identify some difficulties that the sociological approach could confront when coping with the social implications of modern molecular biology, this paper will begin by highlighting some historical points of reference with which we could perhaps point out some peculiarities of these developments. The purpose of this paper is to confront the contemporary idea that 'genes' can represent the main connection between human action and human nature. Therefore, an overview of the origins of sociology will be presented in order to indicate how questions of human nature have greatly influenced the debate on human action in an implicit or explicit way. Aiming to contextualize how challenging it is for sociology to deal with biological questions, the next section intends to show why the creation of well-delimited boundaries between 'nature' and 'social' was crucial for the formation of sociology as a subject. After this contextualization, the contemporary debate on 'human nature' oriented by the advance of biotechnology and genomics will be reviewed in order to assess the consequences of this debate on the sociological problem of human action. Finally, after the reconstruction of some foundational characteristics of sociology, reflections will be presented about how the problem of agency and its relation with the structural dimension of society could play a role in helping to construct knowledge about what changes and challenges in genomics and biotechnology represent to the sociological theory approach.

\section{Genes, genetics, and genomics}

Nowadays, it is almost impossible "to attend to the mass media without hearing of the genes for this or that feature of human physiology or behavior that scientists have discovered or are on the verge of discovering" (Dupré, 2001, p.2). Frequently, these pieces of news suggest that the adequate manipulation of these genes can provide increased and more precise knowledge of life and that they are the key to improving our well-being.

Genes predisposing to diseases such as cancer and heart disease are probably more widely publicized than the journalistically exciting genes for aggression, alcoholism, homosexuality, promiscuity, rape, intelligence, criminality, and so on - "genes that purport to explain the great variety of human behavior and nature. And some scientists and journalists have been more than willing to collaborate in the production of such provocative news" (Dupré, 2001, p.2). 
Some scientists and journalists argue that bioscientific advances will afford an understanding of the whole make-up and functioning of the body simply through an understanding of which genes code with which proteins. This kind of perspective has gained such footing in the public sphere that almost everything about human features that had previously been considered inexplicable or ruled by chance suddenly falls within the realm of possible control and manipulation through biotechnologies. Consequently, some characteristics traditionally considered 'cultural' in a broad sense begin to be regarded as coded by a specific gene.

In short, modern biotechnology is founded on the developments of molecular biology, where the role played by 'genes' has received special attention. Wilhelm Johannsen coined the word 'gene' in 1909 to refer to the hereditary units that compose the characteristics of organisms. In a classic definition, a gene is "a stretch of DNA sequence that codes for a particular protein that has a particular function" (Collins, 2001). In spite of the centrality of the category of gene, some historians and philosophers of biology have argued that there has never been a generally accepted definition of gene in genetics (Falk, 1986; Keller, 2000; Rheinberger, Mueller-Wille, 2004). Moreover, after the recent conclusion of the Human Genome Project, when several uncertainties with regard to the properties and the foundations of genes became visible, we have witnessed the rise of voices inquiring about the validity of talking about genes (Moss, 2003; Dupré, 2004). These questions have stimulated the development of 'genomics', which is concerned with finding out to what extent the genome contains, or is composed of, something that corresponds to the traditional concept of genes. Characteristic traits would only emerge from a certain kind of configuration in a genome and not from specific information stored in a single gene. From Dupré's perspective, 'genomics' could probably be seen as a successor to traditional 'genetics'.

The knowledge of what genes can do is often followed by metaphors such as deciphering, mapping and coding, suggesting an ever increasing control of nature and life through technique, and a kind of preformationist view of the biological development of human beings. To better cope with the polyphonic interpretations about this object, Moss (2003) has been engaged in following the historical reconstruction and conceptual analysis of the meaning of gene. According to Moss's conclusion, it is possible to define and distinguish two different kinds of conceptions of genes:

\footnotetext{
Each of these can be seen as an heir to one of the two major historical trends in explaining the source of biological order: preformationism and epigenesis. The preformationist gene (Gene P) predicts phenotypes but only on an instrumental basis where immediate medical and/or economic benefits can be had. The gene of epigenesis (Gene-D), by contrast, is a developmental resource that provides 'templates' for RNA and protein synthesis but has in itself no determinate relationship to organismal phenotypes. The seemingly prevalent idea that genes constitute information for traits (and blueprints for organisms) is based, [according to this perspective], on an unwarranted conflation of these two meanings which is, in effect, held together by rhetorical glue (Moss, 2003, p.XIV).
}

Are our genes actually responsible for our actions, behavior, or even human nature?

Sociobiologists, now also known as evolutionary psychologists, have tried to provide some sort of biological explanation for these issues. 
Sociobiology is a term that was introduced by E.O. Wilson in 1975, when he wrote Sociobiology: the new synthesis. With this neologism, he intended to open a new field of research within which he could investigate the implications of the evolutionary theory to understand 'human nature'. He has probably been "the most influential recent thinker to conceive of the problem of human nature as a problem in biology" (Dupré, 2003, p.110). One of the claims in sociobiology is that natural selection has adapted many social behaviors, leading to reproductive success; the histories of particular behaviors can, therefore, be reconstructed within an evolutionary framework. These histories can be traced back to the Pleistocene (approximately the last million years), and human nature can be considered as the assemblage of information-processing modules that emerged at that moment (Dupré, 2001, p.110-111).

Wilson very often argued that he thought he could provide support to social scientists, and he never expected such a strong reaction against his ideas. But, in fact, in the mid1980s, sociobiology became an unpopular title, and therefore Dupré (2001) suggests that evolutionary speculations about human behavior started to arise under the rubric of evolutionary psychology.

Evolutionary psychologists believe that they are able to outline a universal human nature. However, they do it in an implicit commitment to an obsolete preformationist view of development. They have created a relationship between human nature and human action, treating the former as the ground for understanding the latter. Human nature is understood as some real essence of the human species: "an internal property of all and only humans that explains their actions and the reasons that motivated them" (Dupré, 2001, p.109).

From this perspective, advances in genetics have given rise to special attention to these researchers, who believe that genes represent the deposit of all human characteristics that have been selected through the evolution of the species. Thus, they provide the most suitable answers to human behavior. Dawkins' (1976) figure of selfish-genes is probably the best expression of this intention.

According to many critics of human sociobiology, standard sociobiological models are inadequate to account for human behavior because they ignore the contributions of mind $^{1}$ and culture. A second criticism concerns genetic determinism, the view that many social behaviors are genetically fixed. Critics of sociobiology often complain that its reliance on genetic determinism, especially of human behavior, provides tacit approval of the status quo. For instance, if male aggression is genetically fixed and reproductively advantageous, critics argue that male aggression seems to be a biological reality (and, perhaps, a biological 'good') over which we have little control. This seems to be both politically dangerous and scientifically implausible (Holcomb, Baker, 2005).

This kind of comprehension comes from "the wholly confused idea that the development of an organism is merely the implementation of a plan or the running of a program somehow written in the DNA, is a paradigm of the consequences of mechanistic distortion" (Moss, 2003). The prevalent ideas that the mere translation of the code, program, or blueprint somehow written in the DNA forms the development of organisms, in both their physiological and behavioral dimensions, lead to certain assertions on public debate that need to be further investigated. 


\section{Origins of sociology: human nature and social order}

It is common today to find scientists in the mass media talking about what genes can or cannot do and trying to explain to the lay public how much these genes are responsible for human behavior and human nature. Even though this kind of idea has become hegemonic, at least in the media, this position is far from being consensual. On the other hand, it is remarkable how this subject, usually addressed by human sciences, has become a subject of scientists dedicated to the sciences of life.

Inquiring about how much sociologists could contribute to this debate, some former elements that helped to build the path of the discipline will be reviewed here in order to better understand the situation of sociological theory in light of the questions generated by the public debate concerning genes.

Before the nineteenth century, there was no sociology as an organized discipline, although the study of society as a historical and empirical object has often been placed as beginning in eighteenth-century France and Scotland. This assertion does not necessarily suggest that eighteenth-century social theory constituted sociology; in fact, it remained a peculiarly invigorating mixture of political philosophy, history, political economy, and sociology (Abel, 1970; Swingewood, 1984, p.7).

From this point of view, it is not uncommon for sociologists or sociology historians to go back to classic Greek thought and to theorists of the Social Contract to pinpoint some foundational bases of the social sciences. Among those who choose to follow this path, it is not surprising to find interpretations that suggest an articulation between human action and human nature.

Even though there is a tendency (as followed by Swingewood, for instance) to elect authors such as Vico, Bacon, and Montesquieu as precursors of sociology due to their historical perspective regarding the role of individuals, few social scientists could deny the influence of Aristotle, Hobbes, Locke, and Rousseau on the approach of social action in sociology and political science. According to Swingewood (1984), for Aristotle the origin of society lies in human nature because humanity is by nature social and political and thus destined to live with other communities. Consequently, instincts such as sexual desire predispose the formation of groups and associations by individuals; essential human nature is further developed by those groupings. "Society was then the expression of an inherent sociability. Aristotle's formulations blocked the possibility of defining society in terms of objective laws and historical processes" (p.8-9).

Later, the social contract theory of Thomas Hobbes (1588-1679) rejected Aristotle's essentialist sociability and created a theory that sought the origins of society in a structure of contractual obligations and reciprocal social relationships. Human nature was still an important component of this theory. However, Aristotle's essentialist sociability was replaced in the work of Hobbes by an asocial, egoistic, and individualistic humanity. Even filled by this asocial definition of human nature, the social contract theory laid the foundations for the secular social theory of the seventeenth century, by assimilating the secular historical nature of human society to the notion of a pre-social, trans-historical human nature. Furthermore, Locke saw human nature as characterized by reason and tolerance, and Jean-Jacques Rousseau developed his dichotomy of a sociable humanity in a state of nature 
(humanity as the product of nature), corrupted by the egoistic fashion of modern civil society (humanity as the product of society and culture) (Swingewood, 1984).

Subsequently, social phenomena came to be perceived as the expression of a transhistorical process, due to this concept of human society and order as based on human nature. In this context, specific characteristics shaped by social context (education, custom, habit) and universal principles of human nature - which were able to address only its uniform features - have led to the dismissal of the social contract theory. One of these uniform features, noted by Hume and Weber, concerns the great mutual dependence of human beings, leading to the fact that almost every human action is performed taking into account the actions of others (Swingewood, 1984).

The 'problem of human action' has constituted a theme of crucial importance in both sociology and philosophy. One of the main sociological questions has to do with the degree of freedom individuals feel when guiding their own action in society. Therefore, explanations about the level of 'autonomy' of individuals in their relationship with society have been major themes in social theory. From this perspective, some issues reappear constantly: are individuals free to lead their own history, or are they constrained by society? Are there human beings outside social collectivities?

In fact, the concept of 'individual' occupied a central position in the creation of typical modern thought. It was interpreted as the fundamental cell of society by authors such as Hobbes and Locke, for example, who formulated a concept of the individual that was characterized by rationality, centeredness, and consciousness of interests. The fall of the Ancien Regime consolidated modernity on the shoulders of the Enlightenment, which has brought in its core the project of 'human emancipation'. This 'project of modernity' idealized a society in which social progress and subject freedom would be its priority. Nevertheless, history shows us that the structures of modernity have proved their inefficiency in implementing their own project (Domingues, 2005, p.35-36).

However, since many social scientists maintained the concept of individual as a central category, sociology has positioned itself as a critical alternative to this Enlightenment notion of social life, as well as to the modern concept of the individual.

As time went by, the contradiction between the emphasis on the concept of society as a system or structure governed by objective law, and the role of the subject in the making of social structure and social change became the major problem of classical sociology (Alexander, jun. 1987; Archer, 1988; Domingues, 2000; Swingewood, 1984, etc.). In this sense, issues about the human nature of social action were not represented as something that sociologists could ask about, even though at least some implicit conceptions supported their explanations.

Some time later, understanding that the development of sociology should not be a history of competing and opposing schools but rather the development of "a substantial common basis of theory" and "sound theoretical foundations on which to build," Talcott Parsons (1961) proposed a convergence of sociological theories towards a "generalized theory of action," based on a comprehension that human action is characterized by its systemic nature. This initial effort of Parsons became one of the most influential tendencies of analysis in sociological theory, inspiring what Jeffrey Alexander (jun. 1987) had called the "new theoretical movement". 
According to Alexander (jun. 1987), the new theoretical movement was shaped around the 1970s and consisted of a set of attempts to overcome the old dichotomies present in sociology and in the social sciences. These dichotomies can be summarized (despite the names and theories of the various authors) into theoretical programs that favor the concepts of action, agency, and process, and those that favor the notions of function, system, and structure. A movement of synthesis would enable us to avoid the one-sidedness of essentially actionalist or essentially functionalist approaches, overcoming these dichotomies. Current attempts at synthesis can be divided into two groups, despite the specificness of each author's approach: those that maintain the analytical division between both dimensions while trying to overcome the dichotomies (for example, Jürgen Habermas' theory of communicative action), and those that aim to articulate both dimensions by devising a new central concept (for example, Anthony Giddens' theory of structuration).

Even if it is outside the scope of this paper to discuss the high price that Mouzelis (1995, p.156) believes sociological theory pays for the subject-object distinction, the proposal of concentrating the analyses upon the problem of agency is placed within the critical context raised by Archer (1988). According to her analysis, there is a series of elements enclosed in the category of agent, just as in the category of structure, which not only are often adequately broached but also get completely subsumed when the synthesis is analyzed.

In this sense, the proposal of this paper to focus its analysis on the character of human action is not meant to defend an analytical separation between agency and structure. The focus on action is meant to argue in favor of the importance of recovering the biological dimension of man as another constitutive element of human action. This movement has crucial relevance in allowing sociological theory to play an active role in the current debate that intends to explain the reasons and dynamics of human action in society.

Such an apparently naive proposal, however, retrieves another classic theme in the social sciences: the relationship between nature and culture. The purpose of building an object characteristic to social sciences nurtured resistances within the disciplinary field regarding biological characters, which can also be understood as stemming from the development of discipline, as will be discussed in the next section.

\section{Sociology, nature, and society}

The dichotomy between nature and society as well as the one between nature and nurture has mobilized intellectual efforts from both social and natural scientists, although each historical moment brings different nuances to their assumptions. According to Bruno Latour (1993), the construction of "distinctive ontological zones" between culture and nature or humans and non-humans, through the exercise of "purification," is one of the most typical characteristics of our time. Besides, he has also argued that this is a (non-) modern illusion, since during this process of purification its opposite occurs: the constant building of new hybrids of nature and culture, called "translations" by Latour. ${ }^{2}$

Therefore, it is reasonable to suppose that in order to address the question of human action in face of the ongoing technicalization of individuals (or, perhaps, of their human nature), it is first necessary to initiate a process of communication between relevant 
disciplines, on the one hand, the natural sciences and, on the other, philosophy and the humanities. From the humanities point of view, this means we are facing a challenge, because we need to deal with the usual diversity of social interpretations and, at least on a basic level, the plurality of assumptions, theories, and results presented by the natural sciences - where there are several theoretical frameworks available, which might very well be based on and lead to different anthropological assumptions.

Returning a little bit to the process of consolidation of sociology as a subject, we can find other features to clarify why the construction of bridges of communication between biosciences and sociological theory represents such a huge challenge.

As mentioned before, in an academic sense, an increasing process of specialization, which had given origin to specific knowledge subjects, marked the nineteenth century. In this context, sociology was born as a subject responsible for explaining the social relationships of modern societies. To better reach this aim, the concept of 'social' was defined by sociology in the widest possible sense (Comissão Gulbenkian, 1996). As a consequence of this process, the category of 'nature' in sociological terms tends to appear as residual. Furthermore, sociologists have often argued that in modern societies we are only able to address a kind of "socialized nature" (Giddens, 1990). This last assessment has been supported by an implicit thesis: that human action has already reached all natural environments, from which the idea that there is no more space for intervention in nature follows as a corollary. In spite of the plausibility of this idea, its former formulation established a connection between nature and biology, which may not be convenient in addressing changes in the biosciences.

However, contemporary developments in genomics and biotechnologies have cast some suspicion on this interpretation, since recent events have suggested that maybe there were some specific natural spaces untouched by the human being: the organic structure itself at a molecular level.

A simple illustration might help to indicate the reasoning from the social theoretical point of view. Imagine a planned garden with living plants, as a very simple example. If a sociologist decided to analyze it, even if the plants in this garden were 'natural', it would be clear to him that the garden was a social object. Issues about the very 'nature' of plants that were part of our imaginary garden weren't part of our social imagination. With the new possibility of manipulating the genetic structure of living beings, this picture will probably not appear in a similar way. Looking at the same garden, someone will probably ask about the origin of the plants, if their species can be found in the natural environment, or if they were 'engineered' in laboratories. This quite simple example shows us that boundaries have been transposed and that territories have been reached by the social. New technological developments have created the possibility of inquiring about the process by which each plant in the artificial garden came into being. These developments lead us to inquire about the 'naturality' or 'artificiality' of those few, but meaningful, things that until now we had simply accepted as 'done by nature'.

From this perspective, it is not implausible to claim that the potential possibilities unleashed by biotechnologies and genomics have allowed us to intervene in the process of production of what we understand as human, nature, and social. 
In fact, the disciplinary constitution of sociology was in great measure characterized by its ambivalent relationship with biology and other disciplines, such as psychology, geography, and human ecology, which incorporate biological variables in their analyses. On the one hand, sociological thought was constituted with strong influence from concepts and methodological postures transferred from biology and the natural sciences in general, which remit us to the ideas of development, evolution, and adaptation of organisms. On the other hand, the development of sociological theory follows a model shaped mainly by contrary reactions to biological reductionisms of several kinds (especially social Darwinism and environmental determinism) (Buttel, 1992).

Bringing the scientific ideal to the point of the strictly social implied that human beings are involved in a historical and non-natural process. 'Social phenomena are not natural' is the founding axiom of mainstream systematic sociological thought, as Durkheim (1984) and Weber (1997) have pointed out. Consequently, disciplinary affirmation of the social sciences occurred while biological variables were rooted out (Parsons, 1961).

In this process of disciplinary specialization, sociology began to investigate events caused by the dynamics of capitalist modernization, more precisely, the pathologies generated by the dissolution of traditional societies and the constitution of modern societies (Habermas, 1987; Giddens, 1990). Therefore, modern society forged social conditions that enabled scientific reflection upon itself.

The industrial revolution of the nineteenth century was followed by a series of cultural and societal upheavals that marked the beginning of fundamental changes in our selfunderstanding as 'human beings'. The establishment of formal knowledge, which included philosophical and social science frameworks, came together with those shifts. Making a parallel, it seems that the new millennium has created new situations, objects, and challenges, which will require some disciplinary reformulations. From this perspective, it also seems that if sociological theory wants to keep its authority in supplying explanations of human agency, a movement towards the construction of a broader analytical framework capable of encompassing the biological dimensions of human beings will probably be necessary.

\section{Human nature in a Genomic Era}

Developments in biotechnology and genomics have had a deep social impact upon both the material and cognitive dimensions. However, in public debate, it seems that the authority for supplying explanations of human action, behavior, and nature has shifted completely from philosophy and the humanities to the natural sciences. Medicine and biology - especially the cognitive sciences and genetic approaches - are assumed to supply an almost unlimited access to 'objective facts' on human evolution, history, and existence (Grunwald, Gutmann, Neumann-Held, 2002).

In this scenario, Jürgen Habermas (2003) and Francis Fukuyama (2003) have dedicated themselves to writing about biotechnology and genetics. At first sight, the coincidences between the arguments of these authors are remarkable. Both of them believe that biotechnologies and genetics are able to produce alterations in human organisms and that people's basic recognition that they are part of the same species could shift. As a 
consequence, we would probably have to reformulate fundamental concepts such as those of freedom, equality, autonomy, recognition, dignity, and so on, or, maybe, in a worse situation, these concepts will not even make sense any more.

To better understand Habermas' concerns, it would be convenient to remember that Habermas' essays about biotechnology were marked by an implicit debate with Peter Sloterdijk. The polemics began during a conference address given in July 1999, at Elmau, Bavaria, by Sloterdijk. His former paper was entitled Regeln für den Menschenpark: Ein Antwortschreiben zu Heideggers Brief über den Humanismus (Rules for the human themepark: a reply to the letter on humanism) and it was published as a book. In this text, Sloterdijk returns and somehow renews the biopower questions, originally formulated by Foucault and Deleuze. Sloterdijk's major worries in this text concern, first, the level of autonomy of individuals while making their own choices facing technical developments. According to the author, we can verify that the power of choice is uncomfortable and that the explicit refusal to exercise the obtained power of selection will soon be a choice towards innocence. Second, in an early diagnosis about the changing potential of genetic engineering, Sloterdijk (1999, p.45-47) told us that if the species' characteristics will suffer a genetic reform in the long term, with advanced future 'anthropotechnology' managing to shape human characteristics, "if the human being leads to a commutation from birth fatalism to optional birth and to prenatal selection - even though in an uncertain and obscure way, the evolutionary horizon begins to show up in front of us".

It would not be exaggerated to conclude that Habermas' main motivations in writing these articles have been political. Precisely, the possibility of eugenics policies is something "that touches an ever raw nerve in the soul of democratic, humanist Germany". ${ }^{3}$ In The future of human nature, Habermas (2003) focuses especially on two aspects of biotechnology: a) eugenic reproduction, and b) the turning point of our ethical self-understanding as members of the same species.

The first of these aspects does not work with the possibility of 'authoritarian' eugenics, which would be closer to the country's dreaded Nazi past. Furthermore, Habermas is very worried about the threats posed by 'liberal' eugenics, especially within a neoliberal atmosphere. From this perspective, the author mentions at least two threats. To begin with, this kind of intervention in the genetic structure of individuals blurs the limits between what we create and what is the result of species' evolution, affecting our understanding of what an individual is. Second, at the intersubjective level, these arbitrary interventions in the genetic structure of human beings will produce asymmetric relationships among those who are 'spontaneously human' and those whose characteristics were artificially manipulated.

Regarding the second aspect, stressing the increasing difficulties in drawing the line that could distinguish between therapy and eugenics, Habermas (2003, p.21) develops the argument that a change in evolution could possibly lead to the 'self-transformation' of the human species, bound up with the understanding of the species as comprising autonomous subjects, hence capable and in need of normative moorings. At this moment, Habermas brings to the core of the argument the risks to which a 'human nature' is exposed and also addresses the possibility that we cannot distinguish between something 'grown' (by nature) from something 'done' (by man). From this perspective, Habermas 
argues that pre-implantation genetic diagnostics (PGD), for instance, represents a direct affront to the very notion of corporeal integrity because it alters what is done by 'nature'. ${ }^{4}$ His work is supported by the presupposition that human beings share the same species and thus the same human nature - and that this characteristic is the basic element that allows us to recognize each other as equal and therefore having the same rights.

Almost at the same moment that Habermas published his book, Fukuyama also took part in the debate, assuming presuppositions similar to Habermas' regarding the fixedness of human nature, but in some sense directing his worries towards the regulation of human nature changes - being at this point closer to Sloterdijk.

Influenced by the emblematic year of 1989 - marked by the fall of the Berlin Wall Francis Fukuyama published his most famous paper: "The end of history?" (Fukuyama, 1989). According to his analyses, global neoliberalism had definitely entered post-industrial capitalism and the democracy of the market. This scope made the future rise of any economic and political alternative to this model impossible, announcing 'the end of history'. According to his perspective, socialism and other 'radical ideologies' failed because they believed too much in human flexibility and, thus, in the possibility of building a 'new man' through environmental influences.

However, this same author, in his book Our posthuman future: consequences of biotechnology revolution (Fukuyama, 2003), revised his former central thesis about the end of history, seeing biotechnology as a central factor to the 'restart of history'. He claims that his former diagnosis was 'right,' although his foundations were equivocal. In order to formulate the thesis about the end of history, Fukuyama had adopted as a basic presumption the existence of a fixed and unchanged human nature, with which it would be possible to stipulate limits to the possibilities of societal development. Nevertheless, for the author, through biotechnology we will be able to reach the expected changes in society that socio-political efforts have not achieved: to breed a new kind of human being. This (virtual) potentiality penetrates in his argument of the 'end of history', since the limit to the new devenir was previously imposed by human nature itself, but at this moment this limit can be transposed by scientific development. In his paper "Second thoughts: the last man in a bottle" (Fukuyama, 1999), it was already possible to find the idea that in a short time - one or two generations - we could replace the older and inefficient disciplinary techniques of domestication by genetics through the precise and efficient design of human beings (Fukuyama, 2003).

Besides their thematic affinity, Habermas and Fukuyama also seem to agree about one point of their conclusions; returning to Aristotelian formulations, both argue about the centrality of 'human nature', since it forms the foundation of our ethical and moral comprehension of the world, emphasizing the urge to create mechanisms to control the use of those technologies. They deal with human nature as "some real essence of human species," some biological ground specific to humans "that explains why they are as they are and why they do as they do". Nevertheless, Dupré (2003, p.109) has argued, "we should all know now that even if there are some kinds of things that have essences, biological kinds are not among them".

Maybe just the distinction between grown and done as a criteria to suggest some separation between nature and culture would be enough to indicate how biotechnology 
blurs these frontiers; but this probably does not suffice as a parameter upon which to fix 'human nature', since the building of techniques to improve and correct some undesirable grown characteristics is also something specific to human beings.

What is remarkable in Habermas' analysis is that, facing the changes announced by biotechnologies, he changed his former formulation about the importance of the biological dimensions of human beings, wherein he progressively diminishes the importance of biological traits as something significant in analyzing social changes. ${ }^{5}$ In other words, he used to evaluate some evolutionary changes in human behavior as something that Dupré (2003) called the "natural history of Homo sapiens".

A possible alternative for dealing with the impacts of biotechnology without returning to such preformationism has been provided by some philosophers of biology, such as Dupré (2003) and Moss (2003), who claim for an epigenetic point of view. From this perspective, "human nature, if it is anything at all, is the upshot of the interaction between a developing human individual and a particular society" (Dupré, 2003, p.111).

An epigenetic approach can be quite relevant to the humanities in general and to sociological theory in particular, helping to build bridges of knowledge between molecular biology and foundational philosophical, social, and political aspects, as well as to provide analytical support in clarifying the ideological weight of several arguments broadly publicized.

\section{Final reflections}

Human action has been a central problem for philosophy, as well as for social theory. Although during the nineteenth-century process of disciplinarization, the articulation between human nature and human action was broken, different readings about the elements involved in the analysis of human agency are implicitly supported by some comprehension (or even the denial) of human nature. However, the twenty-first century has witnessed the increase of voices pointing to the limits of this two-centuries-old disciplinary model due to the proliferation of 'boundary objects'.

On the other hand, several people have suggested that we are in the 'century of genes'. Along with this revolution brought by molecular biology, we have witnessed the progressive change from humanities to natural sciences as the most suitable subjects to address human nature and human action. The media and some scientists are spreading the idea that the gene is the place where our essence is deposited and therefore the key to explaining our physical characteristics and behavior.

Maybe sociological theory has shown its incompleteness in explaining our human action vis-à-vis the situation brought about by modern bioscience, but the perspective of the humanities is certainly still fundamental to addressing these changes. In this sense, along with the understanding that subjects should be prepared to work in an interdisciplinary environment of research, the main proposal of this paper is to call for the incorporation of biological dimensions in social theory in order to address human action. However, in practical terms this means being able to critically analyze, realize, and select among the diversity of natural sciences readings. 
Consequently, preformationist approaches that understand the role played by 'genes' as an amount of information that can precisely identify a specific characteristic or behavior are understood as inadequate due to their reductionist perspective. This perspective believes that all characteristics of individuals are information in the genes, ignoring that the characteristics of human beings are the result of several interactions between biological traits and the environment. I defend the idea that these interactions between physical traits and the environment are acting, through growing complexity, from cellular formation to the process of 'individuation' of human beings. Therefore, in order to provide a broader and more complex approach to these interactions between gene and environment, I maintain the incorporation of an epigenetic point of view by sociological theory in dealing with new questions about what genes can do. The epigenetic approach understands the capacity of genes and the development of all organisms as a result of multiple interactions between the biological features of organisms and their environment.

\section{NOTES}

${ }^{1} \mathrm{~A}$ concern about the role of the mind (brain) in explaining human behavior is one of the main distinctions between sociobiology and evolutionary psychologists.

${ }^{2}$ In this sense, the process of purification, seen by Latour as a necessary condition for Modernity, is never completed, which means we have never been modern. Latour (2004) acknowledged that this thesis may not be completely true - especially in relation to his reflections about pre-modern societies - but he still thinks this is an interesting proposal: the basic link between both processes is that the more hybridization is ignored, the more hybrids are multiplied.

${ }^{3}$ For a critical review of this text, see Domingues, 2004.

${ }^{4}$ With regard to the theme of corporeal integrity, Habermas develops discussions about the differences between 'to have a body' and 'to be a body', stressing the relationship between body/freedom/autonomy. This is probably the aspect that has received most sociological attention due to the question of the Posthuman.

${ }^{5}$ Some ideas regarding Habermas' interpretations of biological developments in human society can be seen in Habermas, 1979.

\section{REFERENCES}

ABEL, Theodore.

Foundation of sociological theory. New York: Random House. 1970.

ALEXANDER, Jeffrey.

O novo movimento teórico. Revista Brasileira de Ciências Sociais, São Paulo, v.2, n.4, p.5-28. jun. 1987.

ARCHER, Margareth.

Culture and agency: a place of culture in social theory. Cambridge: Cambridge University Press. 1988.

BUTTEL, Frederick.

A sociologia e o meio ambiente: um caminho tortuoso rumo à ecologia humana. Perspectiva, São Paulo, v.15, p.69-94. 1992.

COLLINS, Francis.

Glossary of genetic terms: gene. National
Human Genome Research Institute. Available at: http://www.nhgri.nih.gov/DIR/VIP/ Glossary/. Accessed on: Oct. 15, 2005. 2001.

COMISSÃO GULBENKIAN.

Para abrir as ciências sociais. São Paulo: Cortez Editora. 1996.

DAWKINS, Richard.

The selfish gene. Oxford: Oxford University Press. 1976.

DOMINGUES, José Maurício.

Modernity reconstructed. Cardiff: University of Wales Press. 2005.

DOMINGUES, José Maurício.

Review of the future of human nature.

The European Journal of Social Theory, v.7, n.3, p.235-241. 2004. 
DOMINGUES, José Maurício.

Social creativity, collective subjectivity and contemporary modernity. London: Macmillan Press. 2000.

DOMINGUES, José Maurício.

Sociological theory and collective subjectivity. London: Macmillan Press. 1995.

DUPRÉ, John.

Understanding contemporary genomics. Perspectives on Science, Massachusetts, n.12, p.320-338. 2004.

DUPRÉ, John.

On human nature. Human Affairs, Slovakian, n.13, p.109-122. 2003.

DUPRÉ, John.

Human nature and the limits of science. Oxford: Oxford University Press. 2001.

DURKHEIM, Émile.

Da divisão do trabalho social. Lisboa: Editora Presença. 1984.

FALK, Raphael.

What is a gene? Studies in the History and Philosophy of Science, Cambridge, n.17, p.133173. 1986

FUKUYAMA, Francis.

Our post-human nature: consequences of the biotechnology revolution. London: Profile Books. 2003.

FUKUYAMA, Francis.

Second thoughts: the last man in a bottle. The National Interest, Washington D.C., n.56, p.1633. 1999.

FUKUYAMA, Francis.

The end of history? The National Interest,

Washington D.C., n.16, p.3-18. 1989.

GIDDENS, Anthony.

The consequences of modernity. Cambridge: Polity Press. 1990.

GIDDENS, Anthony.

The constitution of society: outline of the theory of structuration. Cambridge: Polity Press. 1984.

GRUNWALD, Armin; GUTMANN, Mathias; NEUMANN-HELD, Eva M. (Ed.).

On human nature: anthropological, biological and philosophical foundations. Berlin: Springer. 2002.

HABERMAS, Jürgen.

The future of human nature. Cambridge: Polity Press. 2003.
HABERMAS, Jürgen.

Teoria de la acción comunicativa: racionalidad de la accíon y racionalización social. Madrid: Ediciones Taurus. 1987.

HABERMAS, Jürgen.

Toward a reconstruction of historical materialism. Boston: Beacon Press. 1979.

HOLCOMB, Harmon; BAKER, Jason.

Sociobiology, Stanford Encyclopedia of Philosophy Online. Available at: http://plato.stanford.edu// archives/win2005/entries/sociobiology/. Accessed on: Nov. 20, 2005. 2005.

KELLER, Ellen Fox.

The century of the gene. Cambridge: MIT Press. 2000.

LATOUR, Bruno.

The social as association. In: Gane, Nicholas. The future of social theory. London: Continuum. p.77-90. 2004.

LATOUR, Bruno.

We have never been modern. Cambridge:

Harvard University Press. 1993.

MOSS, Lenny.

What genes can't do. Cambridge: MIT Press. 2003.

MOUZELIS, Nico.

Sociological theory: what went wrong?

New York: Routledge. 1995.

PARSONS, Talcott.

The structure of social action: a study in social theory with special reference to a group of recent European writers. 2.ed. New York: Free Press of Glencoe. 1961.

RHEINBERGER, Hans-Jörg; MUELLER-WILLE, Staffan.

Gene. Stanford encyclopedia of philosophy.

Available at: http://www.seop.leeds.ac.uk/ entries/gene/. Accessed on: Feb. 15, 2006. 2004.

SLOTERDIJK, Peter.

Regras para o parque humano: uma resposta à carta de Heidegger sobre o humanismo. São Paulo: Estação Liberdade. 1999.

SWINGEWOOD, Alan.

A short history of sociological thought. London: Palgrave Macmillan. 1984.

WEBER, Max.

A 'objetividade' do conhecimento nas ciências naturais. In: Cohn, Gabriel (Ed.). Max Weber. São Paulo: Ed. Ática. (Coleção Grandes Cientistas Sociais). 1997. 